\title{
ROZBIEŻNOŚĆ STRUKTURY WYKSZTAŁCENIA KOBIET I MĘŻCZYZN W PRL. POMIĘDZY POLITYKA PAŃSTWA A INDYWIDUALNYMI WYBORAMI EDUKACYJNYMI
}

\section{Wprowadzenie}

Wiek XX był w krajach zachodnich okresem, w którym dokonał się awans edukacyjny niemal całych społeczeństw. W Polsce, gdzie kontrasty między poziomem wykształcenia poszczególnych warstw społecznych były głębokie, a straty wojenne mocno naruszyły infrastrukturę edukacyjna, nowe władze już w 1944 r. uznały odbudowę systemu szkolnego za priorytet. Jednym z celów polityki oświatowej było upowszechnienie kształcenia wśród młodych pokoleń chłopów i robotników, których możliwości nauki były dotychczas mocno ograniczone. Wystarczy wspomnieć, że w międzywojennej Polsce około 25-30\% chłopów było analfabetami, a ich doświadczenia szkolne kończyły się w wielu rejonach kraju na trzech, czterech klasach szkoły powszechnej ${ }^{1}$. Modernizacja gospodarki i podporządkowanie jej planów oświatowych miały tę sytuację niedługo zmienić. Już w latach 60 . i 70. polski system edukacyjny wypadał dobrze w międzynarodowych zestawieniach: wskaźnik skolaryzacji na szczeblu ponadpodstawowym i ponadśrednim był wyższy niż w wielu krajach Europy Zachodniej ${ }^{2}$. Wysoka pozycja Polski wynikała jednak $\mathrm{w}$ dużej mierze $\mathrm{z}$ istnienia rozbudowanej sieci szkolnictwa zawodowego dla dorosłych oraz różnego rodzaju szkół pomaturalnych, kształcących w trybie innym niż pełne studia uniwersyteckie. Ilościowy rozwój systemu edukacyjnego, który z czasem oferował coraz

${ }^{1}$ J. Żarnowski, Epoka powojenna: 1945-1989, w: Spoteczeństwo polskie od X do XX wieku, red. I. Ihnatowicz, A. Mączak, B. Zientara, J. Żarnowski, Warszawa 2005.

${ }^{2}$ M. Kozakiewicz, Skolaryzacja młodzieży polskiej. Wnioski z wtórnej analizy spisu powszechnego, Warszawa 1976. 
więcej typów szkół i możliwości transferów między nimi, przyniósł jeszcze inny skutek. System, który zaprojektowany był do wyrównania społecznych szans edukacyjnych, doprowadził do powstania rozbieżności w strukturze wykształcenia kobiet i mężczyzn na poziomie ponadpodstawowym oraz zdobycia przez kobiety przewagi na studiach wyższych.

Problematyka osiagnięć edukacyjnych kobiet w Polsce zwracała uwagę badaczy od połowy lat $60 .^{3}$, ale kwestię tę traktowano pobieżnie, pozostawiajacc więcej miejsca badaniom dotyczącym ich rosnącej aktywności zawodowej ${ }^{4}$, adaptacji do nowych warunków gospodarczych ${ }^{5}$ czy ruchliwości w strukturze społecznej ${ }^{6}$. Celem tego artykułu jest analiza rozbieżności struktury wykształcenia kobiet i mężczyzn w okresie PRL oraz wyjaśnienie jej w kontekście głównych hipotez dotyczących wyborów edukacyjnych. Skupię się na proporcji płci w wymiarze międzyszkolnym oraz wewnątrzszkolnym na poziomie ponadpodstawowym i wyższym - interesuje mnie zróżnicowanie między typami szkół, kierunkami oraz trybami nauki. Posłużę się w tym celu danymi zaczerpniętymi z roczników statystycznych. Wnioski z moich analiz pozwola lepiej zrozumieć kształtująca się w PRL segmentację ze względu na płeć na rynku pracy oraz związaną z nią lukę płacową. Mogą też mieć zastosowanie do międzynarodowych porównań, które umożliwią wyjaśnienie wpływu konkretnych rozwiązań oświatowych na formowanie struktury wykształcenia współczesnych społeczeństw.

\section{Przegląd badań i hipotez}

We współczesnych systemach oświaty selekcja między płciami dokonuje się na etapie ponadpodstawowym, gdzie dziewczęta częściej wybierają szkoły ogólnokształcące, a mężczyźni zawodowe. Pod koniec lat 60. odsetek kobiet w szkołach ogólnokształcacych był o około 20 punktów procentowych wyższy niż w pozostałych krajach objętych statystykami UNESCO. Zbliżony do polskiego poziom sfeminizowania istniał

\footnotetext{
${ }^{3}$ R. Wieruszewski, Równość kobiet i mężczyzn w Polsce Ludowej, Poznań 1975; M. Kozakiewicz, dz. cyt.

${ }^{4}$ S. Dzięcielska-Machnikowska, Problemy feminizacji zatrudnienia zawodów $i$ stanowisk $w$ Polsce, „Studia Socjologiczne” 1968, nr 1.

${ }^{5}$ Kobieta wspótczesna. Z badań socjologów, lekarzy, ekonomistów, pedagogów i psychologów, red. M. Sokołowska, Warszawa 1966.

${ }^{6}$ J. Peschar, E.T. Vergert, R. Popping, From Father to Son and from Father to Daughter. Educational Mobility in Hungary and the Netherlands for the Birth Cohorts from 1925 to 1955, „Quality and Quantity” 1986, nr 20(4), s. 377-403.
} 
jeszcze tylko w Czechosłowacji, na Węgrzech i w Rumunii (odpowiednio $65 \%, 68 \%$ i $59 \%)^{7}$. Zdaniem badaczy ${ }^{8}$, większe zainteresowanie Polek wykształceniem humanistycznym było nie tylko przejawem indywidualnych preferencji, ale $\mathrm{w}$ dużej mierze wynikiem powojennej polityki oświatowej, której cechą charakterystyczną był intensywny rozwój segmentu szkół zasadniczych zawodowych. Zgodnie z interpretacja Zbigniewa Sawińskiego, kobiety ze względu na brak interesujacej oferty w szkołach zawodowych ${ }^{9}$ częściej decydowały się na zdobycie matury i dalszą edukację po jej uzyskaniu. Inaczej było w przypadku mężczyzn, którzy chętniej korzystali z możliwości zdobycia zawodu, ale jednocześnie ograniczali swoje możliwości dalszej nauki. Ireneusz Białecki i Barbara Heyns podkreślaja, że powstała w ten sposób rozbieżność w strukturze wykształcenia kobiet i mężczyzn była efektem ubocznym państwowych planów gospodarczych, które dążyły do wzmocnienia siły klasy robotniczej, a nie skutkiem świadomie prowadzonej polityki równościowej ${ }^{10}$. Oficjalne cele działań podejmowanych w kierunku wyrównania szans edukacyjnych pomijały bowiem kwestię płci, skupiając się tylko na pochodzeniu społecznym jednostek.

$\mathrm{Na}$ inny czynnik prowadzący do rozbieżności struktury wykształcenia wskazuja badacze węgierscy. Udział mężczyzn wśród osób kontynuujących naukę w szkołach wyższych w tym kraju spadał w kohortach urodzonych w latach 40. i kolejnych, co Szonja Szelényi i Karen Aschaffenberg wyjaśniaja pojawieniem się atrakcyjnych dla mężczyzn ofert pracy po szkole ponadpodstawowej w latach $60 .{ }^{11} \mathrm{~W}$ konsekwencji tych zmian w niektórych krajach Europy Środkowo-Wschodniej doszło do spowolnienia ruchliwości edukacyjnej mężczyzn, a niekiedy obserwowano wręcz międzygeneracyjną degradację ${ }^{12}$.

${ }^{7}$ International Yearbook of Education, International Bureau of Education, Geneva 1969.

${ }^{8}$ I. Białecki, B. Heyns, Educational Attainment, the Status of Women, and the Private School Movement in Poland, New York 1992; Z. Sawiński, Zmiany systemowe a nierówności $w$ dostępie do wykształcenia, w: Zmiany stratyfikacji społecznej $w$ Polsce, red. H. Domański, Warszawa 2008, s. 13-43.

${ }_{9}^{9}$ Z. Sawiński, dz. cyt., s. 42.

${ }^{10}$ I. Białecki, B. Heyns, dz. cyt., s. 318.

${ }^{11} \mathrm{~S}$. Szelényi, K. Aschaffenberg, Inequalities in Educational Opportunity in Hungary, w: Persistent Inequality. Changing Educational Attainment in Thirteen Counties, red. H.P. Blossfeld, Y. Shavit, Boulder, s. 273-303.

${ }^{12}$ N. Simonová, Educational Inequalities and Educational Mobility under Socialism in the Czech Republic, ,The Sociological Review” 2008, nr 56(3), s. 429-453; B. Mach, Intergenerational Mobility in Poland 1972-88-94, w: Social Mobility in Europe, red. R. Breen, Oxford 2004. 
Wnioski formułowane $\mathrm{w}$ tych pracach dotyczą selekcji dokonujacych się między typami szkół, a pomijają istotny aspekt zróżnicowań wewnattrzszkolnych. Warto wobec tego przyjrzeć się, jakie znaczenie dla powstania rozbieżności wykształcenia między płciami miały selekcje $\mathrm{w}$ horyzontalnym wymiarze struktury oświaty, to znaczy między kierunkami nauki. Postawiona w tym artykule hipoteza mówi, że do powstania rozbieżności przyczynił się system oświaty, którego misją było dostarczenie wykwalifikowanych kadr do rozwijającego się przemysłu. Rozbudowany system szkolnictwa zawodowego nastawiony był przede wszystkim na kształcenie mężczyzn, czego przejawem były m.in. oferowane w szkołach zawodowych kierunki nauki. Kobiety chętniej wybierały wobec tego szkoły maturalne (zazwyczaj licea), co dawało im możliwość kontynuowania nauki na studiach lub w szkołach pomaturalnych. Fakt, że kobiety miały większą preferencję wobec kierunków humanistycznych lub ogólniej rzecz ujmując takich, które kształciły do pracy z ludźmi, a wśród mężczyzn większą popularnością cieszyły się kierunki techniczne, nie było polska specyfika. Badania przeprowadzone w latach 50. i 70. wśród amerykańskich studentów wskazuja na podobna prawidłowośśc ${ }^{13}$. W krajach kapitalistycznych rozbieżności te kształtowały się jednak pod wpływem innego rodzaju bodźców niż w systemie, który głębiej ingerował w kształt systemu edukacji, jak miało to miejsce $\mathrm{w}$ Polsce.

\section{Struktura systemu edukacji w okresie socjalizmu}

Polityka oświatowa PRL ulegała przekształceniom, zarówno $\mathrm{w}$ wymiarze organizacyjnym, jak i funkcjonalnym. Latem $1951 \mathrm{r}$. wprowadzono uchwałę Prezydium Rządu określająca funkcjonowanie szkolnictwa zawodowego w celu „realizacji narodowych planów gospodarczych i budowy podstaw socjalizmu”"14. Planom tym podporządkowany zostać miał wkrótce system oświaty. Powołano np. cztery typy szkół zawodowych: przysposobienia zawodowego, zasadnicze szkoły zawodowe, technika zawodowe oraz szkoły majstrów. Te pierwsze przeznaczone były dla młodzieży powyżej 16. roku życia, która nie ukończyła szkoły podstawowej. Umożliwiały one nabycie elementarnej wiedzy zawodowej w ciagu kilku do kilkunastu miesięcy.

${ }^{13}$ S.W. Polachek, Sex Differences in College Major, „Industrial and Labor Relations Review" 1978, nr 31(4), s. 498-508.

${ }^{14}$ Uchwała nr 448 Prezydium Rządu z 23 VI 1951 r. w sprawie ustroju szkolnictwa zawodowego, „Monitor Polski” 1951, nr 59, poz. 776. 
W praktyce były to szkoły przeznaczone dla młodzieży z najniższymi wynikami w nauce i problemami wychowawczymi. Nauka w szkole zasadniczej zawodowej, początkowo dwu-, a potem trzyletnia, kończyła się uzyskaniem kwalifikacji w określonym zawodzie, natomiast w technikach, oprócz zdobycia wiedzy technicznej, dawała również maturę.

Od początku lat 60., zgodnie z postanowieniem ustawy o rozwoju systemu oświaty i wychowaniu, obok szkół zasadniczych zawodowych istniały szkoły zawodowe obejmujące technika zawodowe i licea zawodowe oraz szkoły policealne dla osób mających maturę. Ustawa z $1961 \mathrm{r}$. powoływała jeszcze szereg innego rodzaju szkół zawodowych, np. dla nauczycieli czy mistrzów. Równolegle funkcjonowały również technika dla przodujących robotników oraz powołane w latach 70 . średnie studia zawodowe, przeznaczone dla osób, które już funkcjonowały na rynku pracy. Rozdrobnienie szkół zawodowych sprawiało, że niektóre ich typy kształciły niewielką liczbę młodych ludzi. Większą stabilność organizacyjną w porównaniu ze szkołami zawodowymi miały licea ogólnokształcące. Reformy je obejmujące ograniczały się przede wszystkim do zmian w programach nauczania, warunkach rekrutacji czy sposobie uzyskania świadectwa ukończenia szkoły. Od lat 60. podejmowano też nieudane próby większego uzawodowienia tych szkół. Pojawiły się m.in. pomysły różnicowania programu kształcenia dla uczniów, którzy wybierali się na studia i dla tych, którzy zamierzali poprzestać na uzyskaniu matury. Postulowano też organizowanie specjalnych zajęć przysposobienia zawodowego w szkołach zlokalizowanych w miejscowościach bez dostępu do szkół zawodowych ${ }^{15}$. Bardziej owocne okazało się jednak tworzenie trwajacych dwa lub trzy lata szkół, które umożliwiały łatwiejsze przechodzenie między ścieżkami zawodowymi i ogólnymi ${ }^{16}$.

Najbardziej charakterystyczną cechą oświaty w socjalistycznej Polsce była wyraźna przewaga liczebna szkolnictwa zawodowego nad liceami. Tendencję tę widać na wykresie 1 . Do lat 70 . priorytetem był rozwój zasadniczych szkół zawodowych, które szczyt swojego rozwoju osiagnęły w 1970 r., ale już kolejne lata były okresem intensywniejszego rozwoju szkół technicznych. Trwało to aż do 1980 r., gdy oba trendy zostały wyhamowane. Na marginesie warto wspomnieć, że rozwój sieci szkół zawodowych nie oznaczał wcale, że edukacja w nich cechowała się dobra jakością. Już w raporcie dotyczącym kondycji oświaty przygotowanym w latach 70 . krytyce poddane zostało przestarzałe wyposażenie

${ }^{15}$ M. Pęcherski, System oświaty w Polsce Ludowej na tle porównawczym, Wrocław 1981.

${ }^{16}$ Tamże. 
warsztatów i nieadekwatność programów wobec wymagań rynku pracy. Podobne głosy można było również usłyszeć w latach 90., ale w tej dekadzie powstała również opinia o negatywnej selekcji uczniów do tych szkół oraz braku perspektyw zawodowych absolwentów.

Wykres 1. Liczba szkół ponadpodstawowych w Polsce w latach 1955-1995

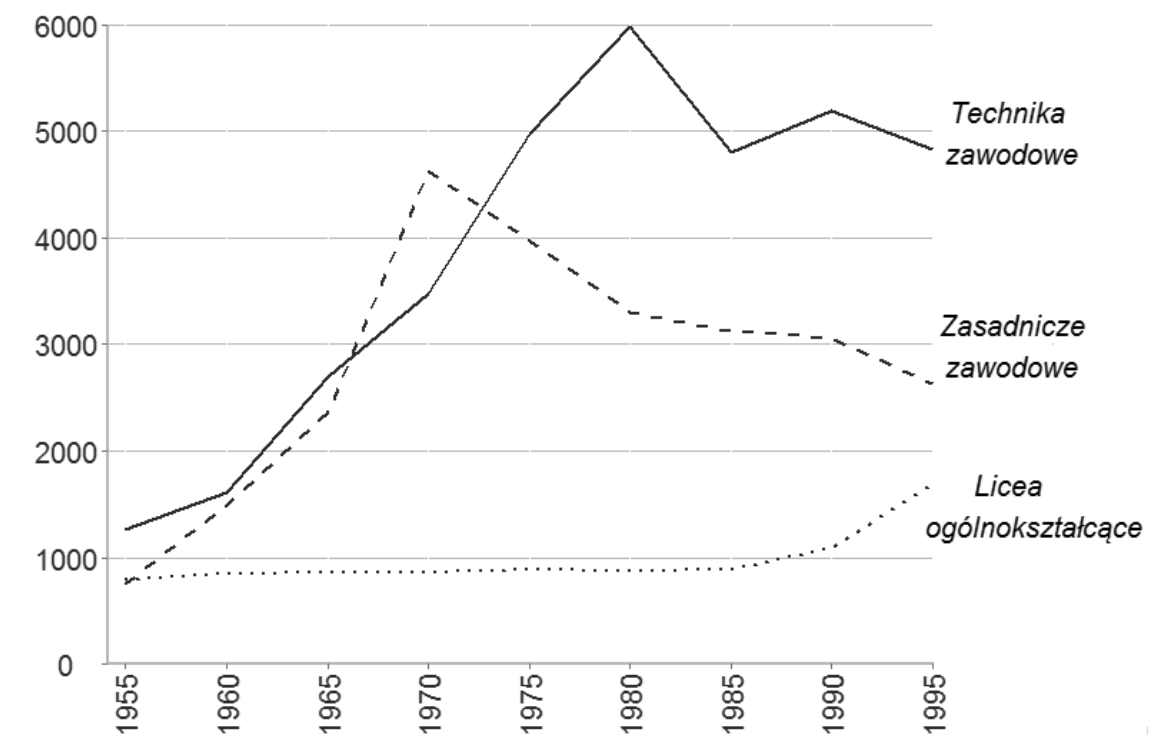

Źródło: oprac. własne na podstawie Roczników Statystycznych z lat 1956, 1961, 1966, 1971, 1976, 1981, 1986, 1991, 1996.

\section{Wybory edukacyjne po szkole podstawowej u schyłku PRL}

Dane urzędowe, którymi będę się posługiwała w dalszej części artykułu, mają tę zaletę, że umożliwiają porównania między płciami na poziomie kierunków i typów szkół. Jest to podstawowa różnica względem wykorzystywanych często $\mathrm{w}$ takich analizach danych sondażowych oraz wcześniejszych analiz na ten temat. Klasyfikacje poziomu wykształcenia używane $\mathrm{w}$ badaniach prowadzonych na próbce, nawet te najbardziej szczegółowe, składały się zwykle z kategorii odnoszących się jedynie do hierarchicznie rozumianego wymiaru oświaty ${ }^{17}$. Do najpoważniejszych ograniczeń danych GUS zaliczyć zaś trzeba zmieniający się w poszczególnych latach sposób agregowania danych, który utrudnia

${ }^{17}$ Z. Sawiński, Pomiar $i$ skalowanie wykształcenia $w$ badaniach socjologicznych, Warszawa 1986. 
prowadzenie analiz w czasie. Chodzi tu przede wszystkim o grupowanie kierunków nauki w szkołach zawodowych, którego szczegółowość zmieniała się $\mathrm{w}$ poszczególnych publikacjach ${ }^{18}$. Z tego względu większość przedstawionych informacji dotyczących kierunków nauki pochodzić będzie z Rocznika Statystycznego Szkolnictwa z 1987 r., w którym GUS przedstawił szczegółowe statystyki.

Podstawowym wskaźnikiem rozbieżności struktury wykształcenia jest udział płci w trzech typach szkół na poziomie ponadpodstawowym. Na wykresie 2 . widać, że udział kobiet wzrastał we wszystkich typach szkół, chociaż nie w jednakowym tempie: w latach 1955-1985 odsetek kobiet w liceach zwiększył się o 14 punktów procentowych, w technikach spadł o 3 punkty, a w szkołach zasadniczych zawodowych wzrósł aż o 19. Pozwala to zweryfikować często powielaną opinię, że szkoły zasadnicze zawodowe były zdominowane przez mężczyzn przez cały okres PRL. Teza taka była niewątpliwie prawdziwa dla lat 50. i początku następnej dekady, ale później kobiety decydowały się na taką ścieżkę edukacyjną niewiele rzadziej niż na technika.

Wykres 2. Odsetek kobiet w szkołach poszczególnych typów w latach 1955-1995

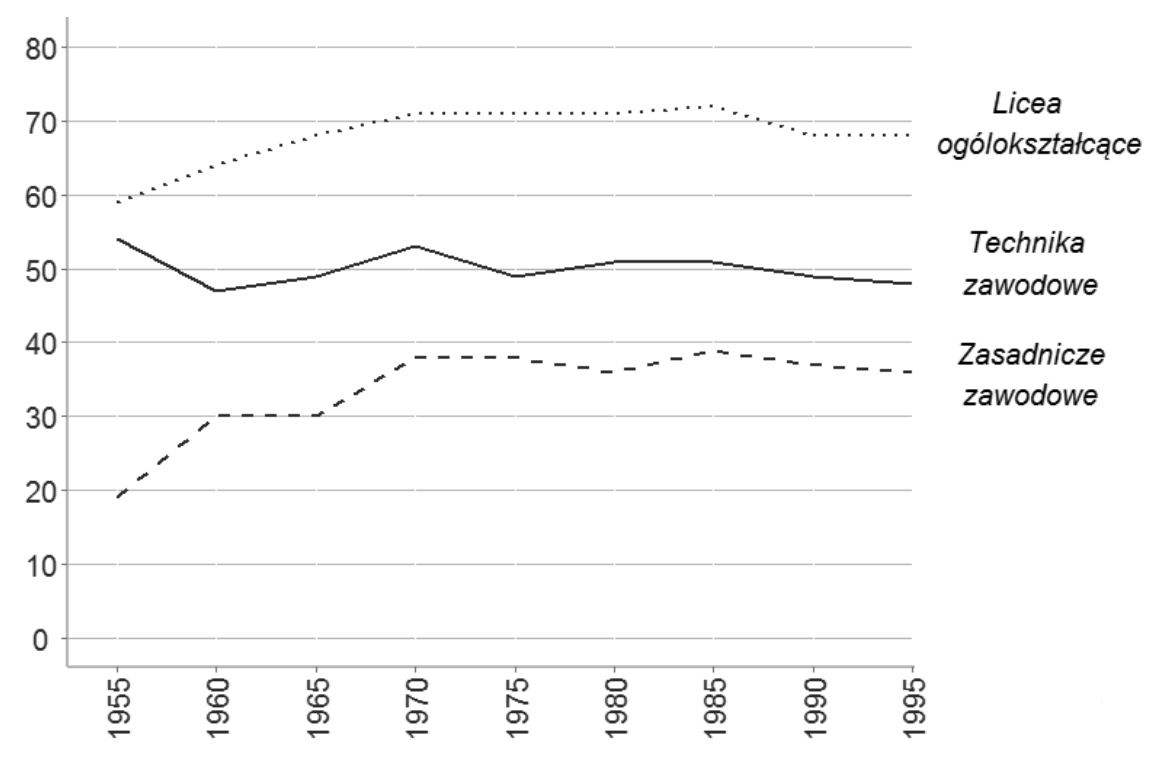

Źródło: zob. wykres 1.

${ }^{18}$ Spowodowane było to również zmianami w klasyfikacji zawodów. Na przykład w 1964 r. Komitet Pracy i Płac opracował nową nomenklaturę zawodów, z której wynikało, że w szkołach zasadniczych zawodowych powinno się kształcić w 1210 zawodach, podczas gdy Rocznik prezentuje zaledwie kilkanaście. 
O sporym i rosnącym zainteresowaniu kobiet szkołami zasadniczymi przekonuje również wykres 3., który przedstawia wybory absolwentów szkół podstawowych z trzech roczników: 1960, 1970 i 1980 (odsetki sumuja się do 100\%). Odsetek kobiet wybierajacych szkoły zasadnicze zawodowe wśród wszystkich kobiet kontynuujących naukę po szkole podstawowej wynosił odpowiednio: 37, 50 i 43 . Z powodu niedoskonałości danych GUS nie sposób jednak systematycznie prześledzić, w jakim stopniu za odsetki te odpowiadaja zmiany w ofercie edukacyjnej, a w jakim inne czynniki natury społecznej. Jednak w porównaniu z mężczyznami proporcja ta była wciąż względnie niewielka - w latach 70. prawie trzy czwarte mężczyzn rozpoczęło naukę w szkole tego typu. Inaczej było w przypadku liceów, które od lat 50. znajdowały się przede wszystkim w polu zainteresowania kobiet, ale z czasem, podobnie jak mężczyźni, wybierały tę szkołę rzadziej. Wśród kobiet rosło zaś zainteresowanie technikami.

Wykres 3. Wybory dziewcząt i chłopców po szkole podstawowej w latach 1960-1980 (\%)

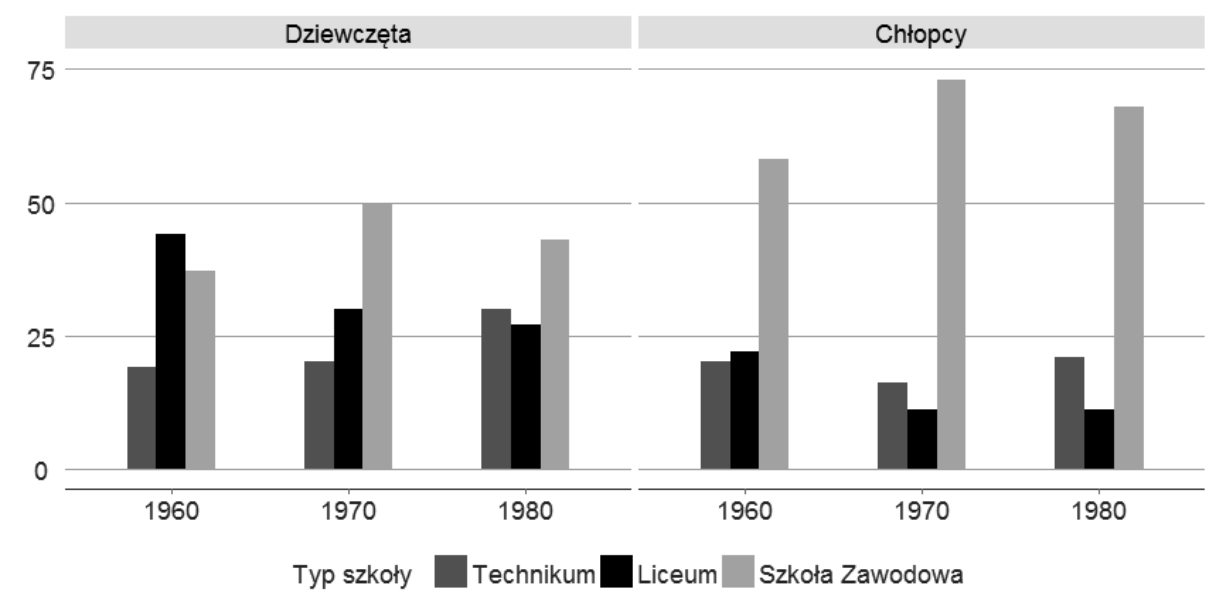

Źródło: oprac. własne na podstawie: Rocznik Statystyczny 1970/1971; Rocznik Statystyczny 1981/1982.

W kontekście tych informacji warto zwrócić uwagę na dwa fakty. Niemal do końca lat 80. więcej mężczyzn niż kobiet kontynuowało naukę w jakiejkolwiek kolejnej szkole ponadpodstawowej. Choć różnice te były nieznaczne, moga wskazywać na większe wyselekcjonowanie kobiet i „odsiew” tych o najniższych wynikach. Jednocześnie dziewczęta pod koniec nauki w szkole podstawowej miały lepsze wyniki w nauce i wyższe aspiracje ${ }^{19}$. Bez wątpienia były to ważne argumenty za pominięciem

${ }^{19}$ Z. Kwieciński, Selekcje społeczne w szkolnictwie ponadpodstawowym, Warszawa 1975. 
szkół zasadniczych zawodowych na rzecz maturalnych. Trzeba także pamiętać, że zasadnicze szkoły zawodowe były pierwszym wyborem wszystkich pokoleń dorastających w socjalizmie bez względu na płeć. Do 1970 r. dostarczyły one $45 \%$ ogółu pracowników zatrudnionych $\mathrm{w}$ sektorach przemysłowych ${ }^{20}$. Biorąc pod uwagę zapotrzebowanie rynku na kwalifikacje zawodowe, pozostałe typy szkół nie były tak bezpiecznymi ścieżkami prowadzącymi ze szkoły do pracy. Aspekt ten mógł być szczególnie istotny dla grup społecznych, które znajdowały się na drodze międzypokoleniowego awansu.

Biorąc pod uwagę złożoną strukturę systemu oświaty, a szczególnie istnienie $\mathrm{w}$ jej ramach wielu możliwości kształcenia dla pracujaccych, warto również skomentować proporcje płci w tym obszarze. W przypadku zawodówek selekcja między poszczególnymi szkołami była wyraźna niemal wyłącznie dla mężczyzn zarezerwowane były szkoły przysposobienia zawodowego, zasadnicze szkoły przyzakładowe i szkoły mistrzów. Tworzyły one „ścieżkę kompensacyjną" dla uczniów, którzy zbyt wcześnie wypadli z systemu albo od razu po szkole podstawowej weszli na rynek pracy. Uczniów szkół tego typu było jednak bardzo mało, przykładowo w latach 70. i 80. stanowili oni od 2 do 3\% wszystkich uczniów szkół zasadniczych. Można też odnieść wrażenie, że różnego rodzaju szkoły przyzakładowe, a w szczególności zasadnicze, tworzone były właśnie z myślą o dokształcaniu mężczyzn, którzy już zdobyli pewne kwalifikacje $\mathrm{w}$ zakładzie pracy i potrzebowali jedynie ich oficjalnego potwierdzenia. Nieco inaczej wyglądało to w przypadku techników dla dorosłych. Kobiety stanowiły nieco mniej niż połowę uczniów szkół dla pracujących i w ramach tej formuły najczęściej wybierały naukę w trybie zaocznym, rzadziej wieczorowym. Na różnicę tę wpływ mógł mieć fakt, że wybory edukacyjne kobiet silniej niż mężczyzn kształtowane były przez posiadanie potomstwa i pozostawanie w związku małżeńskim.

Selekcje w wymiarze horyzontalnym, a więc między kierunkami w szkole danego typu, uzależnione są od czynników instytucjonalnych oraz indywidualnych preferencji. Badacze socjalistycznego systemu oświaty byli zgodni, że jego struktura była ściśle powiązana z planami gospodarczymi, ale niewiele miejsca poświęcili roli jednostkowych wyborów. Dlaczego zatem kobiety rzadziej decydowały się na naukę w szkołach zawodowych, mimo że absolwenci tych szkół znajdowali się $\mathrm{w}$ relatywnie korzystnej sytuacji na rynku pracy?

Istnieją dwie grupy hipotez wyjaśniających wybór kierunku nauki ze względu na płeć. Jedna z nich analizuje wybory w kategoriach różnie

${ }^{20}$ M. Pęcherski, dz. cyt., s. 197. 
rozumianych zwrotów, jakie uzyskuje się po ukończeniu danego kierunku. W zależności od przyjętego modelu teoretycznego zakłada się, że jednostki szacuja własne perspektywy na rynku pracy lub potencjalny dochód, biorąc pod uwagę szansę ukończenia danego kierunku, a więc przede wszystkim ocenę własnych kompetencji ${ }^{21}$. Wybory analizuje się również z perspektywy kulturowej, a więc wpływu, jaki na decyzje kobiet i mężczyzn miał proces socjalizacji czy istniejące stereotypy na temat ról społecznych. Uniwersalny wzór wyłaniajacy się z tych badań wskazuje, że dziewczęta częściej wybierają kierunki związane z opieka, interakcją z ludźmi, edukacja, a mężczyźni związanymi z obsługa maszyn i urządzen ${ }^{22}$. Wniosek ten formułowany był dla współczesnych krajów kapitalistycznych, ale spodziewać się można, że podobne różnice zaobserwować można będzie również wśród polskiej młodzieży dorastającej w socjalizmie.

Przekonuje o tym już analiza tabeli 1 . Zawiera ona informacje na temat udziału kobiet wśród absolwentów niektórych kierunków szkół zasadniczych zawodowych z $1987 \mathrm{r}$. W tabeli tej znajdują się tylko te kierunki, na których liczba absolwentów stanowiła więcej niż $2 \%$ absolwentów wszystkich kierunków nauki. W pierwszej kolumnie znajduje się pozycja w rankingu wielkości (1. to kierunek najbardziej liczny, 13. - najmniej). W drugiej kolumnie przedstawiona jest proporcja kobiet na danym kierunku, a w trzeciej informacje o stosunku absolwentek na danym kierunku do ogólnej liczby absolwentek wszystkich kierunków. Tę ostatnią kolumnę można interpretować jako wskaźnik „stłoczenia" kobiet.

Wśród kierunków, które pod koniec socjalizmu opuściło najwięcej absolwentów, tylko na dwóch liczba kobiet była zbliżona do liczby mężczyzn (piekarze i rolnicy). Na pozostałych proporcja płci była silnie zachwiana. Kobiety miały dużą przewagę na kierunkach, które przygotowywały do tradycyjnie kobiecych zawodów (krawiectwo, sprzedawcy), a tylko niewielki odsetek kobiet decydował się na wybór kierunku technicznego. Te ostatnie były niemal całkowicie homogeniczne pod względem płci. Przykładowo dwa kierunki o największej liczbie absolwentów w analizowanym roku to mechanik maszyn, który ukończyło $2 \%$ kobiet, oraz sprzedawca, który ukończyło 98\% kobiet. Wśród wszystkich

${ }^{21}$ S. Polachek, dz. cyt., s. 498-508; B. Boudarbat, C. Montmarquette, Choice of Fields of Study of University Canadian Graduates. The Role of Gender and Their Parents' Education, „Education Economics” 2009, nr 17(2), s. 185-213.

${ }^{22}$ R. Su, J. Rounds, P.I. Armstrong, Men and Things, Women and People. A Meta-Analysis of Sex Differences in Interests, „Psychological Bulletin” 2009, nr 135(6), s. $859-884$. 
103 wymienionych kierunków 40 było takich, na których kobiet było więcej niż $60 \%$ ogółu uczniów i 56 takich, gdzie było ich mniej niż 40\%. Mniej było też kierunków, na których kształciły się tylko kobiety (5 kierunków związanych z produkcją odzieży) niż takich, na których kształcili się wyłącznie mężczyźni (20). Kolumna trzecia wskazuje na spora koncentrację kobiet na kierunku sprzedawcy - uczyło się tam $21 \%$ kobiet oraz krawieckim, gdzie uczyło się kolejne 14\%. Jeśli więc kobiety decydowały się na naukę w szkole zawodowej, pole ich wyboru było dość mocno ograniczone, do dwóch, trzech kierunków. Dobrze ilustruje to, jaki wpływ na jednostkowe wybory szkolne miała istniejąca struktura oświaty: w obrębie szkół zawodowych było bardzo mało kierunków, które mogły się wydawać interesujace dla kobiet żyjących $\mathrm{w}$ tamtym okresie.

Tabela 1. Odsetek kobiet wśród absolwentów największych grup kierunków zawodowych w 1987 r. (wśród grup zawodów stanowiących więcej niż $2 \%$ wszystkich absolwentów) w szkołach zasadniczych zawodowych, posortowane według kolumny 2 (0 oznacza, że liczba kobiet była mniejsza niż 1\%)

\begin{tabular}{|c|c|c|c|}
\hline Kierunek zawodowy & $\begin{array}{c}\text { Ranking } \\
\text { wielkości } \\
\text { (1) }\end{array}$ & $\begin{array}{c}\begin{array}{c}\text { Odsetek } \\
\text { kobiet } \\
\text { na kierunku }\end{array} \\
\text { (2) }\end{array}$ & $\begin{array}{c}\text { Odsetek } \\
\text { absolwentek na } \\
\text { danym kierunku } \\
\text { do ogólnej } \\
\text { liczby } \\
\text { absolwentek } \\
\text { (3) }\end{array}$ \\
\hline Szwacze i pokrewni & 13 & 100 & 6 \\
\hline Sprzedawcy i pokrewni & 2 & 98 & 21 \\
\hline Krawcy i pokrewni & 5 & 98 & 14 \\
\hline Kucharze & 10 & 81 & 7 \\
\hline Piekarze i pokrewni & 12 & 58 & 4 \\
\hline $\begin{array}{l}\text { Rolnicy upraw polowych } \\
\text { i pokrewni }\end{array}$ & 3 & 40 & 7 \\
\hline Tokarze i wytaczarze & 9 & 9 & 1 \\
\hline Stolarze i pokrewni & 6 & 7 & 1 \\
\hline Elektromechanicy & 8 & 5 & 0 \\
\hline Ślusarze i pokrewni & 4 & 4 & 1 \\
\hline $\begin{array}{l}\text { Elektromonterzy urządzeń } \\
\text { elektrycznych }\end{array}$ & 7 & 3 & 0 \\
\hline Mechanicy maszyn i urządzeń & 1 & 2 & 0 \\
\hline Monterzy maszyn i urządzeń & 11 & 1 & 0 \\
\hline
\end{tabular}

Źródło: oprac. własne na podstawie: Rocznik Statystyczny Szkolnictwa 1987/1988. 
Wobec istotnej dysproporcji płci na kierunkach technicznych w szkołach zawodowych władze oświatowe PRL podejmowały pewne działania zaradcze. W 1967 r. Ministerstwo Oświaty i Szkolnictwa Wyższego ustaliło minimalną liczbę dziewcząt, które miały być przyjęte na niektóre kierunki i specjalizacje techniczne. Kandydatki, zgodnie z zaleceniami władz oświatowych, miały być traktowane łagodniej podczas egzaminów wstępnych i całego procesu nauki. Oprócz tego zintensyfikowano działania informacyjne zachęcające dziewczęta do nauki na profilach technicznych, m.in. poprzez pojawiające się $\mathrm{w}$ prasie artykuły promujące naukę na tych kierunkach ${ }^{23}$. Nieco później, w 1970 r., podobne limity planowano wprowadzić dla liceów, z tym że tutaj dotyczyły one liczby mężczyzn, którzy mieli stanowić co najmniej 40\% ogółu uczniów. Wobec tych zamierzeń za pewną niekonsekwencję można uznać fakt, że jeszcze w połowie latach 60 . niektóre szkoły techniczne w ogólne nie przyjmowały dziewcząt. Ograniczenia tego doświadczyły m.in. absolwentki szkół podstawowych w Płocku ${ }^{24}$, gdzie miejscowe technikum mechaniczne i szkoła zawodowa metalowa w ogóle nie przyjmowały dziewcząt.

Jak widać z danych zawartych w tabeli 1 . działania te, będące pewna odmianą akcji afirmatywnej, nie przyniosły zamierzonych skutków. Watpliwe bowiem, aby decyzje dziewcząt wynikały z niewiedzy o możliwości nauki na kierunku montera czy elektryka. Istniały inne silne czynniki odwodzące kobiety od takich wyborów. Wśród nich znajdował się niekorzystny bilans nakładów, dochodu i prestiżu zawodowego z jednej strony, a bariery społeczne z drugiej. Kobiety decydujące się na naukę w szkołach zawodowych miały do wyboru kierunki techniczne albo sfeminizowane, ale jak pokazują badania z tamtego okresu, żadna z tych alternatyw nie wiązała się ze stabilizacją zawodowa, dobrymi dochodami czy ponadprzeciętnym społecznym poważaniem.

\section{Przyczyny i konsekwencje wyborów edukacyjnych}

Uruchamianie nowych fabryk i kombinatów stworzyło wiele miejsc pracy również dla kobiet. Jednak badania przeprowadzone w latach 60 . i 70., gdy równolegle do rozwoju infrastruktury gospodarczej wytwarzała się zakładowa kultura pracy, pokazuja, że kobiety od razu zajęły

${ }^{23}$ R. Wieruszewski, dz. cyt., s. 85.

${ }^{24}$ A. Preiss-Zajdowa, $Z$ badań losów absolwentów szkót podstawowych w Ptocku, „Notatki Płockie” 10, 1965, nr 3-4, s. 54-58. 
niższe pozycje w załogach robotniczych. Trudno jednoznacznie ocenić, czy większy wpływ miała na to faworyzująca mężczyzn polityka zatrudnienia, istniejąca już $\mathrm{w}$ tamtych latach rozbieżność $\mathrm{w}$ strukturze wykształcenia pracowników fizycznych na lokalnych rynkach pracy, specyfika miejsc pracy czy może wszystkie te czynniki jednocześnie. Ze spora pewnościa można natomiast potwierdzić, że pracodawcy wykazywali silna preferencję wobec zatrudniania mężczyzn, nawet słabiej wykształconych ${ }^{25}$. Zdarzało się również tak, że do pracy w fabrykach pierwszeństwo przed kobietami miała „trudna” młodzież płci męskiej, która pozostawiona bez pracy mogła stanowić potencjalnie zagrożenie dla porządku publicznego. Trudno jednak oszacować, jak powszechne były tego rodzaju praktyki.

Jak wskazałam wyżej, spora część kobiet, które zdecydowały się na naukę w szkole zawodowej, wybierała kierunki sfeminizowane. Wśród nich najbardziej popularny był profil przygotowujacych do zawodu sprzedawcy, który w drugiej połowie lat 80 . skupiał aż $2 / 5$ wszystkich kobiet kształcących się $\mathrm{w}$ tych szkołach. Mimo wzrostu formalnego wykształcenia tej grupy zawodowej, prestiż tego zawodu w porównaniu z „męskimi”, dostępnymi w ofercie szkół zawodowych (np. mechanika), był relatywnie niski. W gospodarce ciagłego niedoboru praca sprzedawcy otoczona była aura podejrzeń związanych z nielegalnym rozprowadzaniem towarów (sprzedawaniem „spod lady”), a pracownicy sklepów obarczani byli odpowiedzialnością za brak dostępności towarów. Istniało też przekonanie o niskiej złożoności pracy sprzedawców, a wynagrodzenia tej grupy stanowiło w latach $60.80 \%$ średniej krajowej $^{26}$. Również w hierarchii prestiżu zawodowego ekspedientka lokowała się bardzo nisko - za nią był jedynie zawód sprzątaczki i robotnika niewykwalifikowanego w $\mathrm{PGR}^{27}$.

Analizując ofertę szkół zawodowych i strukturę płci na poszczególnych kierunkach, można dojść do wniosku, że dziewczęta, które kierowały się do nich, miały przed sobą dwie równie mało atrakcyjne alternatywy. Jedna z ich było podjęcie nauki na kierunkach technicznych i późniejsza praca $\mathrm{w}$ męskim środowisku, które z powodu czy to faktycznej rywalizacji o posadę, czy psychologicznej niechęci miało do nich

${ }^{25}$ Kobieta współczesna...; R. Wieruszewski, dz. cyt.; J. Tulski, Postawy młodych robotników wobec pracy zawodowej, w: Kobieta wspótczesna..., s. 259-273.

${ }^{26}$ M. Mazurek, Społeczeństwo kolejki. O doświadczeniach niedoboru 1945-1989, Gdańsk-Warszawa 2010.

${ }^{27}$ A. Sarapata, Pozycja społeczna zawodów handlowych we wspótczesnym społeczeństwie polskim, w: Socjologia handlu. Wybrane zagadnienia, red. A. Koźmiński, A. Sarapata, Warszawa 1972, s. 401-415. 
negatywny stosunek. Wejście kobiet do załóg robotniczych było utrudnione, a nagrody $\mathrm{z}$ pracy relatywnie mniejsze $\mathrm{w}$ porównaniu do tych, które otrzymywali mężczyźni. Luka płacowa nie dotykała zreszta jedynie kobiet pracujących fizycznie, ponieważ 30-35\% różnica w pensjach istniała we wszystkich pozostałych zawodach, również wśród specjalistów z wyższym wykształceniem. Drugim wyjściem było podjęcie nauki w zawodzie tradycyjnie sfeminizowanym (np. sprzedawcy), ale to również nie dawało im dobrej pozycji na rynku pracy, jaką cieszyć się mogli np. mechanicy. Popyt na pracę ekspedientki w rzeczywistości pustych półek nie mógł być duży, a warunki pracy w zakładach włókienniczych daleko odbiegały od akceptowalnych standardów.

Wnioski te można przenieść na bardziej ogólny poziom. Analiza procesu industrializacji $\mathrm{w}$ krajach zachodnich przekonuje, że natężenie selekcji ze względu na płeć w szkole i na rynku pracy zależy od etapu rozwoju gospodarczego. Inaczej będą kształtowały się podziały w gospodarce, która większość swojego kapitału wytwarza poprzez pracę intelektualna, a inaczej gdy decydujący udział ma siła mięśni. Fakt, że w socjalizmie istotna część ludności czynnej zawodowo stanowili robotnicy musiał odcisnąć swój ślad na segmentacji płci. Wyjaśniając lukę płacową w industrializującej się Anglii, Joyce Burnette twierdzi, że za niemała jej część odpowiedzialne były różnice biologiczne, ale rozumiane w najbardziej elementarny sposób, a więc poprzez większa siłę fizyczną mężczyzn i monopol kobiet na rodzenie dzieci. Zdaniem badaczki siła odgrywała szczególnie duże znaczenie w dobrze wynagradzanych zawodach robotniczych i rolnych, ponieważ premia za nią była większa niż straty, jakie ponosiły kobiety z tytułu macierzyństwa ${ }^{28}$. Choć gospodarka Anglii w XIX w. i Polski w początkowych dekadach socjalizmu różniły się pod wieloma względami, to dokonując uogólnienia, można powiedzieć, że jedna i druga była w dużej mierze oparta na pracy fizycznej. Jeśli więc priorytetem ekonomicznym jest rozwijanie sektorów przemysłu ciężkiego, to ważnym kryterium selekcji do zawodu będzie właśnie siła fizyczna, która będzie też lepiej nagradzana.

Analizując proporcję kobiet i mężczyzn uczących się w szkołach zawodowych, trudno pominać hipotezę mówiąca, że kobiety mają skłonność do wybierania kierunków nauki oraz zawodów, które umożliwią im pracę z ludźmi, a mężczyźni - z rzeczami ${ }^{29}$. Należałoby więc oczekiwać kobiet na kierunkach związanych $\mathrm{z}$ edukacja, opieka, kierowaniem

${ }^{28}$ J. Burnette, Gender, Work and Wages in Industrial Revolution Britain, Cambridge 2008, s. 12 .

${ }^{29}$ R. Su, J. Rounds, P.I. Armstrong, dz. cyt. 
ludźmi, a mężczyzn przy obsłudze maszyn, urządzeń i projektowaniu. Porównanie tych dyspozycji z ofertą kierunków wyjaśnić może, dlaczego szkoły zasadnicze zawodowe przyciagały proporcjonalnie mniej kobiet niż technika. Tabela 2 . przedstawia strukturę płci w szkołach technicznych. Pod koniec istnienia PRL szkoły te oferowały 54 główne kierunki kształcenia - na 25 kobiety stanowiły więcej niż $60 \%$ uczniów. Tutaj również, podobnie jak w szkołach zasadniczych, na pierwszym miejscu pod względem liczby absolwentów znajdowali się przyszli mechanicy, a drugi największy kierunek - ekonomiczny - był silnie sfeminizowany (95\% udziału kobiet).

Tabela 2. Odsetek kobiet wśród absolwentów największych grup zawodowych w $1987 \mathrm{r}$. (wśród grup zawodów stanowiących więcej niż $2 \%$ wszystkich absolwentów) w technikach zawodowych, liceach zawodowych i średnich studiach zawodowych, posortowane według wielkości proporcji kobiet (0 oznacza, że liczba kobiet była mniejsza niż 1\%)

\begin{tabular}{|c|c|c|c|}
\hline Kierunek zawodowy & $\begin{array}{c}\text { Ranking } \\
\text { wielkości } \\
\text { (1) }\end{array}$ & $\begin{array}{l}\text { Odsetek } \\
\text { kobiet na kie- } \\
\text { runku } \\
(2)\end{array}$ & $\begin{array}{c}\text { Odsetek } \\
\text { absolwentek na } \\
\text { danym kierunku } \\
\text { do ogólnej liczby } \\
\text { absolwentek } \\
\text { (3) }\end{array}$ \\
\hline Nauczyciel przedszkola & 15 & 100 & 3 \\
\hline Pielęgniarka & 3 & 99 & 14 \\
\hline Odzieżowy & 13 & 98 & 4 \\
\hline Sprzedawcy i pokrewni & 6 & 97 & 8 \\
\hline Technik ekonomista & 2 & 95 & 24 \\
\hline Chemik & 11 & 79 & 3 \\
\hline Technologii żywienia & 10 & 78 & 4 \\
\hline Technologii żywności & 16 & 69 & 2 \\
\hline Rolnik & 5 & 55 & 6 \\
\hline Społeczno-prawny & 12 & 51 & 2 \\
\hline Budownictwa & 9 & 29 & 2 \\
\hline Mechanicy maszyn i urządzeń & 7 & 25 & 2 \\
\hline Elektronik & 8 & 7 & 0 \\
\hline Mechanik & 1 & 4 & 2 \\
\hline Elektryk & 4 & 4 & 0 \\
\hline Mechanizacji rolnictwa & 14 & 2 & 0 \\
\hline
\end{tabular}

Źródło: zob. tab. 1. 
Ten wzór selekcji nie jest zaskakujacy, ale wskazuje na inna ciekawa kwestię. Pokazuje, jak na proporcję płci wpływa sama oferta kierunków - istnienie większej liczby kierunków związanych z profesjami sfeminizowanymi przyciagało więcej kobiet do szkół technicznych. Zawody związane $\mathrm{z}$ opieka czy edukacją wymagaja zazwyczaj dłuźszej nauki, obejmującej obszerny blok humanistyczny, której „zawodówki” nie oferowały. Mimo że więcej kobiet niż mężczyzn wybierało technika, to indeks rozbieżności wyboru ze względu na płeć był identyczny w szkołach zasadniczych zawodowych i technikach, i wynosił D $-0,76^{30}$. Oznacza to, że w obu typach szkół $76 \%$ kobiet lub mężczyzn musiałoby zmienić kierunek kształcenia, aby rozkład płci był taki sam. Decyzja o wyborze szkoły podyktowana była zatem nie tylko jej typem, ale raczej kierunkiem zawodowym w niej istniejącym. Przekonuje to, że na różnice struktury wykształcenia kobiet i mężczyzn w znacznej mierze miała wpływ sama struktura systemu edukacji.

Hipoteza mówiąca o większej preferencji kobiet wobec kierunków wymagajacych kompetencji społecznych wymaga dalszego uszczegółowienia w odniesieniu do szkół zawodowych. Mechanizacja produkcji sprawiła, że pracownicy fabryk i dużych zakładów, bez względu na płeć, wykonywali swoja pracę za pośrednictwem maszyn. Różnica w porównaniu do mężczyzn polega na tym, że kobiety obsługiwały maszyny i urządzenia wymagające raczej precyzji niż dużego wysiłku fizycznego. Historycznym przykładem może być silnie sfeminizowany przemysł włókienniczy. Analiza struktury płci absolwentów pokazuje, że liczba kobiet była większa na kierunkach zarówno związanych właśnie z obsługa urządzeń precyzyjnych i „lekkich”, jak i wśród aparatowych różnych specjalności, operatorów urządzeń do obróbki drewna, introligatorów czy laborantów.

Przyczyn rozbieżności struktury wykształcenia w szkołach zawodowych można też poszukiwać, analizując opinie społeczne na temat kulturowych ról kobiet i mężczyzn. Na tle rosnącej aktywności zawodowej kobiet względnie stabilne i powszechne było przekonanie o naturalnym charakterze segmentacji zawodowej. W latach 80. 4/5 Polek uważało, że nie wszystkie zawody moga być wykonywane przez kobiety

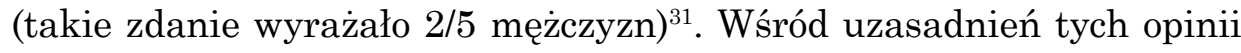

${ }^{30}$ Indeks rozbieżności D to połowa bezwzględnej różnicy między proporcją kobiet na danym kierunku do ogólnej liczby kobiet a proporcją mężczyzn na danym kierunku do ogólnej liczby mężczyzn. Przyjmuje wartość od 0 do 1, gdzie 1 oznacza stan maksymalnej segregacji, a 0 jej brak.

${ }^{31}$ I. Reszke, Prestiż społeczny a płeć. Kryteria prestiżu zawodów i osób, Wrocław 1984. 
wymieniano konieczność angażowania wysiłku fizycznego, szkodliwość dla zdrowia czy stres. Istniała też interesująca asymetria w cechach zawodów, które nie powinny być wykonywane przez kobiety i mężczyzn - kobiece nie są zawody, które wymagają siły fizycznej, a niemęskie te, które związane są ze specyficznymi predyspozycji osobowościowych (np. empatia, opiekuńczość) ${ }^{32}$. Ciekawe zreszta, że ta ostatnia norma nie dotyczyła lekarzy. Pracę zawodową kobiet zatrudnionych w męskich zawodach darzono też mniejszym szacunkiem niż gdy te same zawody wykonywali mężczyźni. Dotyczyło to m.in. kobiety inżyniera, która podwładni mniej szanowali ponieważ, jak można było dowiedzieć się z pytań otwartych cytowanego tu badania Ireny Reszke: „nie będzie z nimi wódki pić" albo że „chłopy na budowie ordynarne”.

Wyniki tych i innych badań ilustrują świadomość społeczeństwa, które operuje silnymi stereotypami dotyczącymi ról płciowych. Przekroczenie tych barier, a więc wybór zawodu niezgodnego $\mathrm{z}$ rolą społeczna, wiązać się musiał z psychologicznymi kosztami ponoszonymi zarówno w najbliższym środowisku, jak i miejscu pracy. Z podobnymi trudnościami musieli liczyć się ci mężczyźni, których bardziej niż projektowanie sieci elektrycznej interesowała praca nauczyciela nauczania początkowego - ich, podobnie jak kobiet w męskich zawodach i kierunkach nauki, było niewielu. Przeanalizowane dane pozwalaja też stwierdzić, że na poziomie edukacji ponadpodstawowej relatywnie większa część kobiet niż mężczyzn dokonywała korzystniejszych wyborów, decydując się częściej na szkoły maturalne oraz dzienne. Kombinacja tych dwóch czynników dawała im przewagę na kolejnym etapie kształcenia.

\section{Kontynuacja nauki po ukończeniu szkoły średniej}

Oprócz tego, że więcej kobiet niż mężczyzn uczyło się w liceach, więcej otrzymywało też świadectwo dojrzałości, a więc miało możliwość podjęcia dalszej nauki. Przykładowo w 1984 r. wśród absolwentów liceów otrzymujących świadectwo maturalne było 70\% kobiet, maturzystki stanowiły też około połowę absolwentów szkół technicznych. Czy kobiety wykorzystały tę szansę na dalszą edukację? Dane dotyczące liczby studentów na pierwszym roku studiów dziennych pokazuja, że w okresie powojennym było wśród nich więcej mężczyzn, ale w latach 1960-1980 dysproporcja między płciami stawała się coraz mniejsza.

\footnotetext{
${ }^{32}$ Tamże, s. 168, 172.
} 
Kobiety uzyskały natomiast przewagę liczebną wśród osób, które ukończyły studia (zob. tabela 3). To proste zestawienie informuje o istotnym procesie selekcji ze względu na płeć, jaki dokonywał się na wyższym szczeblu edukacji: więcej kobiet odpadało na etapie rekrutacji (skądinąd ciekawe byłoby przekonanie się, czy wprowadzony okresowo mechanizm „punktów za pochodzenie” nie dawał w praktyce preferencji którejś z płci), ale więcej mężczyzn rezygnowało w trakcie studiowania.

Tabela 3. Odsetek kobiet na pierwszym roku studiów dziennych i wśród absolwentów studiów dziennych pięć lat później

\begin{tabular}{c|c}
\hline $\begin{array}{c}\text { Rok } \\
\text { szkolny }\end{array}$ & $\begin{array}{c}\text { Odsetek studentek } \\
\text { na studiach dziennych }\end{array}$ \\
\hline 1960 & 39 \\
\hline 1970 & 44 \\
\hline 1980 & 49 \\
\hline
\end{tabular}

\begin{tabular}{c|c}
\hline Rok szkolny & $\begin{array}{c}\text { Odsetek absolwentek } \\
\text { studiów dziennych }\end{array}$ \\
\hline 1965 & 47 \\
\hline 1975 & 51 \\
\hline 1985 & 54 \\
\hline
\end{tabular}

Źródło: oprac. własne na podstawie: Rocznik Statystyczny Szkolnictwa 1968/1969; Rocznik Statystyczny Szkolnictwa 1987/1988.

Obok pełnych studiów wyższych istniały też cieszące się sporym powodzeniem szkoły pomaturalne (inaczej policealne, nazwane potem policealnymi studiami zawodowymi). Od momentu ich powstania w latach 60. były one silnie feminizowane - w latach 1970-1986 kobiety stanowiły ponad 3/4 ich absolwentów, a w kolejnych latach jeszcze więcej. Szkoły te nastawione były głównie na kształcenie przyszłej kadry pedagogicznej przedszkoli i klas nauczania początkowego, personelu medycznego niższego szczebla czy techników ekonomistów. Na tych kierunkach odsetek kobiet wahał się między 84 a 94\%. Wygląda więc na to, że polityka oświatowa kreowała wybory edukacyjne nie tylko na poziomie szkół ponadpodstawowych, gdzie kierowała mężczyzn i kobiety na odmienne ścieżki. Tendencję tę zaobserwować można również na szczeblu pomaturalnym, który stwarzał większe możliwość zdobycia niepełnego wyższego wykształcenia kobietom niż mężczyznom. Warto w tym miejscu przypomnieć, że uczniowie liceów charakteryzowali się korzystniejszą niż uczennice struktura pochodzenia społecznego (więcej chłopców niż dziewcząt miało rodziców z wykształcaniem wyższym) i jako grupa silniej wyselekcjonowana mieli łatwiejszy dostęp do studiów wyższych.

Drugim powodem niższego udziału kobiet wśród studentów pierwszego roku studiów dziennych mógł być sposób rekrutacji. Na niektórych kierunkach istniały sztywno ustalone limity określające, jaki 
odsetek kobiet i mężczyzn możne zostać przyjęty na dany rok akademicki. Przykładowo na wydziałach: rolnym, weterynarii i melioracji dla kobiet zarezerwowanych było co najmniej $25 \%$ miejsc $^{33}$. Najwięcej kontrowersji wzbudzało jednak istnienie limitów przyjęć na wydział lekarski (po 50\%) i stomatologiczny (30\% mężczyzn i 70\% kobiet). Tak rozumiana polityka wyrównywania szans edukacyjnych nie spotkałaby się zapewne z protestem, gdyby nie fakt, że o studiowanie na kierunku lekarskim ubiegało się więcej kobiet niż mężczyzn. Na przykład pod koniec lat 60 . kobiety stanowiły $61 \%$ osób zdających na ten kierunek, a wśród osób nieprzyjętych stanowiły $70 \%^{34}$. Prowadziło to do sytuacji, w których osoba $\mathrm{z}$ wyższa liczba punktów nie zostawała przyjęta, ponieważ wypełnione były już miejsca przewidziane dla jej płci. Jedna $\mathrm{z}$ takich spraw $\mathrm{w}$ drugiej połowie lat 80. trafiła do sądu pod zarzutem niekonstytucyjności i niezgodności z międzynarodowymi postanowieniami. Ministerstwo Zdrowia broniło wtedy istnienia limitów, twierdząc, że niektóre kierunki (głównie chirurgiczne) wymagaja specjalnych cech psychofizycznych, którymi dysponują mężczyźni. Chodziło m.in. o to, że kobiety mają ograniczoną możliwość sprawowania całodobowej opieki nad pacjentami ze względu na rolę macierzyńska. Argumentowano także, że niektóre kierunki, jak np. radiologia, zagrażają zdrowiu kobiet, ich funkcji macierzyńskiej i w końcu, że konieczne jest wykształcenie odpowiedniej liczby lekarzy mężczyzn na wypadek mobilizacji ${ }^{35}$. Uzasadnienia te nie przekonały jednak Trybunału Konstytucyjnego, który orzekł, że ustalone limity są niezgodne z konstytucja oraz ustawą o szkolnictwie wyższym i wezwał ministra zdrowia do uchylenia tych przepisów. W praktyce w kolejnych latach równowaga płci na kierunku lekarskim utrzymywała się.

Poza wyżej opisanymi istniała jeszcze inna prawidłowość - w procesie rekrutacji na studia kobiety względnie częściej ponosiły porażkę na kierunkach z przewagą liczebną kobiet, a mężczyźni na kierunkach z przewagą liczebną mężczyzn. Innymi słowy, łatwiej było się dostać na studia tam, gdzie dominowała płeć przeciwna ${ }^{36}$. Zgodnie z tym większa

${ }^{33}$ R. Wieruszewski, dz. cyt., s. 95.

${ }^{34}$ Tamże.

${ }^{35}$ Orzeczenie Trybunału Konstytucyjnego z 3 III 1987 r. w sprawie określania limitów przyjęć, zakresu egzaminu wstępnego oraz zasad przyznawania punktów dodatkowych w akademiach medycznych; Orzeczenia Trybunatu Konstytucyjnego, Warszawa 1987, s. 20-32.

${ }^{36}$ Istnienie podobnego mechanizmu opisał i zaobserwował Pierre Bourdieu w książce Reprodukcja. Elementy teorii systemu nauczania, tłum. E. Neyman, Warszawa 2006. 
selektywność wobec kobiet istniała na uniwersytetach, gdzie pod koniec lat 60. wśród kandydatów było $32 \%$ mężczyzn i $68 \%$ kobiet, a wśród przyjętych $37 \%$ mężczyzn i $63 \%$ kobiet $^{37}$. Jak pokazuje tabela 4 . proporcje płci na poszczególnych kierunkach studiów przypominają w dużej mierze te istniejące na poziomie szkół średnich ponadpodstawowych: kobiety częściej studiowały kierunki społeczne i humanistyczne oraz przyrodnicze i matematyczne niż techniczne. Porównanie najbardziej licznych kierunków wskazuje jednak, że kobiety miały nieco większą reprezentację na niektórych kierunkach uważanych za „męskie”, np. na budownictwie stanowiły prawie 1/3 ogółu studiujących. Można więc odnieść wrażenie, że w porównaniu z niższymi szczeblami kształcenia tutaj różnice ze względu na płeć nie były tak ostre.

Istnienie rozbieżności struktury wykształcenia nieuchronnie kształtowało też pozycję obu płci na rynku pracy. Absolwentki liceów i studiów wyższych zasilały kadry sektora usług i administracji, co w latach 60. i 70. doprowadziło do feminizacji tych zawodów. Z badań porównawczych przeprowadzonych w krajach bloku socjalistycznego wynika, że kobiety w Polsce miały wyższy status zawodowy niż mężczyźni, choć różnica ta nie była tak duża jak w innych krajach Europy Środkowo-Wschodniej ${ }^{38}$. Ciekawie wypada też porównanie średniej na skali prestiżu zawodowego we wspomnianej części świata i w USA. W tym ostatnim kraju przeciętny prestiż zawodowy kobiet przewyższył status mężczyzn dopiero w 1998 r., natomiast Polki osiagnęły to już w 1980 r. Wong wyjaśnia ten wzrost pozycji kobiet dwiema hipotezami: instytucjonalnym i infrastrukturalnym wsparciem umożliwiajacym szybki powrót do pracy oraz dobrym wykształceniem na poziomie średnim. Chodzi o feminizację liceów, których absolwentki zasilały zawody średniego szczebla. Część mężczyzn, mając ekwiwalentny dyplom ukończenia technicznej szkoły średniej, karierę zawodową rozwijała w zawodach częściowo fizycznych, o mniejszym prestiżu, ale niejednokrotnie większym dochodzie.

${ }^{37}$ R. Wieruszewski, dz. cyt., s. 92.

${ }^{38}$ R. Sin-Kwok Wong, Occupational Attainment in Eastern Europe under Socialism, „The Future of Market Transition” 2002, nr 19, s. 191-230. 
Tabela 4. Odsetek kobiet wśród absolwentów największych kierunków kształcenia w 1987 r. (wśród grup zawodów stanowiących więcej niż 2\% wszystkich absolwentów), posortowane według wielkości proporcji kobiet

\begin{tabular}{|c|c|c|c|}
\hline Kierunek zawodowy & $\begin{array}{c}\text { Ranking } \\
\text { wielkości } \\
\text { (1) }\end{array}$ & $\begin{array}{l}\text { Odsetek kobiet } \\
\text { na danym } \\
\text { kierunku } \\
\text { (2) }\end{array}$ & $\begin{array}{c}\text { Odsetek } \\
\text { absolwentek } \\
\text { na danym } \\
\text { kierunku } \\
\text { w stosunku do } \\
\text { ogólnej liczby } \\
\text { absolwentek } \\
\text { (3) }\end{array}$ \\
\hline Nauczanie początkowe & 3 & 97 & 7,9 \\
\hline Biologia & 16 & 87 & 3 \\
\hline Filologia polska & 9 & 85 & 4,9 \\
\hline Pedagogika & 10 & 81 & 4 \\
\hline Stomatologia & 18 & 78 & 2,3 \\
\hline Matematyka & 14 & 73 & 2,9 \\
\hline $\begin{array}{l}\text { Ekonomika i organizacja obrotu } \\
\text { towarowego }\end{array}$ & 15 & 70 & 2,5 \\
\hline Ekonomika i organizacja produkcji & 8 & 65 & 4,1 \\
\hline Lekarski & 2 & 54 & 6,1 \\
\hline Inżynieria środowiska & 17 & 49 & 1,5 \\
\hline Rolnictwo & 6 & 49 & 3,1 \\
\hline Prawo & 5 & 49 & 3,3 \\
\hline Historia & 12 & 46 & 2,1 \\
\hline Administracyjny & 13 & 37 & 1,5 \\
\hline Wychowanie fizyczne & 11 & 35 & 1,6 \\
\hline Budownictwo & 4 & 29 & 2,2 \\
\hline Mechanika & 1 & 6 & 0,9 \\
\hline Elektrotechnika & 7 & 6 & 0,4 \\
\hline
\end{tabular}

Źródło: oprac. własne na podstawie: Rocznik Statystyczny Szkolnictwa 1987/1988.

\section{Podsumowanie}

Celem artykułu była analiza rozbieżności struktury edukacyjnej ze względu na płeć w okresie PRL. Dotychczasowe ustalenia - oparte na analizach różnych typów szkół - wskazywały, że głównym źródłem tej rozbieżności była struktura oświaty z dominującym sektorem szkół zawodowych. Analizy dokonane w tym artykule pozwoliły na 
uszczegółowienie i uzupełnienie tych konkluzji. Po pierwsze, odsetek kobiet w szkołach zasadniczych zawodowych wzrastał i na początku lat 90. osiagnał stosunkowo wysoki poziom (prawie 40\%). Mimo sporego udziału kobiet ogółem, w wymiarze horyzontalnym były one skoncentrowane na kilku sfeminizowanych kierunkach. Dysproporcja w liczbie kierunków oferowanych dla kobiet i mężczyzn w szkołach zawodowych jest jednym z powodów omawianej tu rozbieżności. Drugi związany był z różnicą w gęstości sieci szkół zawodowych i liceów oraz tym, że $\mathrm{w}$ niektórych rejonach kraju istniały formalne ograniczenia w dostępnie kobiet do szkół zawodowych. Wśród pozostałych powodów wymienić należy uogólnione wzorce kulturowe wyznaczające zakres dopuszczalnych i niedopuszczalnych wyborów zawodowych. Myśląc o „wyborze” edukacji, trzeba więc pamiętać, że poza klasycznymi czynnikami, takimi jak pochodzenie społeczne czy miejsce zamieszkania, pokolenia dorastające $\mathrm{w}$ socjalizmie doświadczyły również charakterystycznych dla tego systemu ograniczeń narzuconych przez politykę oświatowa. Mężczyźni, będący rezerwuarem siły roboczej, stali się głównymi beneficjentami rozwoju szkolnictwa zawodowego. Ubocznym efektem zmaskulinizowania zasadniczych szkół zawodowych stało się „wypchnięcie” znacznej części kobiet do równoległych ścieżek edukacyjnych - szkół średnich, zwłaszcza liceów. Ścieżki te często okazywały się bardziej korzystne z punktu widzenia całościowych karier zawodowych, ponieważ części z nich otworzyły drogę do zdobycia wykształcenia wyższego bądź policealnego. Znamienne zreszta, że reformy liceów miały w okresie PRL charakter jedynie kosmetyczny - podjęto nieudane próby ich większego uzawodowienia. Być może częściowo dzięki fiasku tych planów pozostały atrakcyjną alternatywą dla bardziej uzdolnionych kobiet pochodzących z różnych klas społecznych.

Przedstawione analizy pokazuja, że powojenne reformy, które w założeniach miały doprowadzić do łatwiejszego awansu edukacyjnego zdominowanej przez mężczyzn klasy robotniczej, stały się w perspektywie kolejnych pokoleń bariera tego awansu, ograniczały bowiem pewnej kategorii mężczyzn możliwość przejścia do zawodów umysłowych. Uzyskana z czasem edukacyjna przewagę kobiet można zatem interpretować jako niezamierzony skutek krótkowzrocznych reform edukacyjnych, zorientowanych przede wszystkim na aktualne zapotrzebowania rynku pracy. 


\section{Bibliografia}

Białecki I. Heyns B., Educational Attainment, the Status of Women, and the Private School Movement in Poland, New York 1992.

Burnette J., Gender, Work and Wages in Industrial Revolution Britain, Cambridge 2008.

Kobieta wspótczesna. Z badań socjologów, lekarzy, ekonomistów, pedagogów i psychologów, red. M. Sokołowska, Warszawa 1966.

Kozakiewicz M., Skolaryzacja młodzieży polskiej. Wnioski z wtórnej analizy spisu powszechnego, Warszawa 1976.

Kwieciński Z., Selekcje społeczne $w$ szkolnictwie ponadpodstawowym, Warszawa 1975.

Mazurek M., Społeczeństwo kolejki. O doświadczeniach niedoboru 1945-1989, Gdańsk-Warszawa 2010.

Pęcherski M., System oświaty w Polsce Ludowej na tle porównawczym, Wrocław 1981.

Polachek S., Sex Differences in College Major, „Industrial and Labor Relations Review" 1978, nr 31(4), s. 498-508.

Reszke I., Prestiż społeczny a płeć. Kryteria prestiżu zawodów i osób, Wrocław 1984.

Sawiński Z., Zmiany systemowe a nierówności $w$ dostepie do wykształcenia, w: Zmiany stratyfikacji społecznej w Polsce, red. H. Domański, Warszawa 2008.

$\mathrm{Su}$ R., Rounds J., Armstrong P.I., Men and Things, Women and People. A Meta-Analysis of Sex Differences in Interests, „Psychological Bulletin” 2009, nr 135(6), s. 859-884.

Szelényi Sz., Aschaffenberg K., Inequalities in Educational Opportunity in Hungary, w: Persistent Inequality. Changing Educational Attainment in Thirteen Counties, red. H.P. Blossfold, Y. Shavit, Boulder 1992, s. 273-303.

Wieruszewski R., Równość kobiet i mężczyzn w Polsce Ludowej, Poznań 1975.

Wong R. Sin-Kwok, Occupational Attainment in Eastern Europe under Socialism, „The Future of Market Transition” 2002, nr 19, s. 191-230.

Alicja Zawistowska

The divergence in the structure of the education of men and women in the Polish People's Republic. Between the state policy and individual educational choices

(Summary)

In the era of the Polish People's Republic, the gender divergence in the structure of education grew in parallel with an increase in the number of women who obtained secondary and higher school education. The analysis given in the article supplements our knowledge on the topic with details 
concerning the male/female ratio in vocational and technical education. Based on the analysis presented here, it is possible to specify two factors which, while linked to the educational policy pursued in communist Poland, stood behind the divergence under discussion. First, vocational schools offered training in trades reserved mainly for men, which led women to opt for high school general education. Second, women's access to some 'male' schools was formally restricted. Women's educational advantage, which was the result of the policy conducted by the state in the field of education, can thus be regarded as having been an unintentional side effect of the reforms introduced in Poland after the Second World War.

Key words: educational reforms, unintentional consequences, gender, the Polish People's Republic 